\title{
Reassessing Japanese American Collective Memory Through Gene Oishi's Internment Narratives
}

Nicolangelo Becce

Università degli Studi Roma Tre, Italia

\begin{abstract}
Seven decades after Japanese Americans were interned during the Second World War, former journalist and internment survivor Gene Oishi published Fox Drum Bebop (2014). The protagonist, Hiroshi, had been introduced in Oishi's previous memoir, In Search of Hiroshi (1988), as "quasi-fictional" and "neither American nor Japanese, but simply me". Yet, in the same memoir, Oishi had also described his inability to write about 'Hiroshi', thus settling on 'Gene' as a main character and waiting 28 more years before publishing a book about his true self. A comparison between the two books highlights that In Search of Hiroshi was written as an attempt at telling a story that would implicitly support the 'model minority' myth by offering an account of the internment experience as a direct response to the sociopolitical constraints related to the request by Japanese Americans for redress from the U.S. government. On the other hand, the more recent Fox Drum Bebop represents a fictional retelling of Oishi's memoir which reveals the limits of the collective memory of the internment as developed during the redress years by openly defying the 'model minority' stereotype while at the same time once more denouncing the injustices suffered by the Japanese American community during the war. This essay focuses on Oishi's double narrative as a reassessment of the collective memory of the internment experience and of its lasting effects on Japanese Americans.
\end{abstract}

Keywords Japanese American Internment. Japanese American Literature. Memory Studies. Model Minority. Gene Oishi.

Summary 1 Introduction. - 2 Gene Oishi and His Search for Hiroshi. - 3 Finding Hiroshi Three Decades Later. - 4 A New Internment Narrative Against the Long-Lasting 'Model Minority' Myth.

\section{Peer review}

Submitted 2021-04-01

Accepted 2021-05-24

Published 2021-08-29

\section{Open access}

(C) 2021 | @(i) Creative Commons Attribution 4.0 International Public License 
"Jesus, Hiro", Harry said. “I hope you don't go around saying that to hakujin".

"I'm not only saying it", Hiroshi said, "I'm thinking of writing a book about it".

(Gene Oishi, Fox Drum Bebop, 2014)

\section{Introduction}

The tragic internment of Japanese Americans during the Second World War undeniably became a defining moment in the history of the United States, and it radically affected the lives of generations of Americans of Japanese ancestry ever since. Based on racial prejudice, the internment was the result of Executive Order 9066, signed by President Franklin Delano Roosevelt on February 19, 1942 as a direct consequence of the attack on Pearl Harbor by the Japanese Army. EO 9066 rapidly put the process of incarcerating about 120,000 Japanese American people, living in large areas of the Pacific Coast of the United States, in motion. Composed by U.S. citizens for more than two thirds, the Japanese American communities living on the West Coast were compulsorily removed from their homes, forced to quickly dispose of their property, and then transferred to internment camps hastily built in remote areas of the country.

Understandably, the internment also left an indelible mark on the literary production of Japanese American writers in the following decades. As pointed out by Sato:

internment narratives, whether comprising a whole text or only part of a larger work, have been continuously produced from 1942 through the present. $(2009,453)$

Both Sato and Robinson (2015) categorize the literary production of internment memories by Japanese American writers into four periods, with the first one being related to the years 1942-46, that is the time when the internment was enforced. Japanese American inmates wrote about their experience from within the relocation camps, as is the case with Miné Okubo's graphic memoir Citizen 13660 (1946), which was drafted during her internment at the Tanforan Assembly Center (CA) first and at the Topaz War Relocation Center (UT) later, or Hisaye Yamamoto's "Death Rides the Rails to Poston" (1942), a mystery originally published in four installments in a newspaper printed at the Poston Relocation Camp (AZ). The second period, which roughly corresponds to the end of the 1940s and the two following decades, is marked by the urge felt by the Japanese American community to leave the trauma of the internment behind in order to blend in with the American society as quickly as possible. As a consequence, only few works about the internment experience were published during 
those years, among which the then almost ignored novel No-No Boy by John Okada (1957), which only became popular after being republished by Asian American author and scholar Jeffrey Chan in $1976 .^{1}$

Starting from the 1970s, and as a direct consequence of the civil rights movement, Japanese Americans became more proactive toward uncovering and publicly discussing the traumatic history of the internment during the Second World War. They promoted campaigns aimed at obtaining formal reparations from the U.S. government, which ultimately led to an official redress in 1988. This, according to Sato, can be considered as the "third phase of internment memory" $(2009,454)$, which sees an explosion in terms of published narratives about the internment. ${ }^{2}$ Robinson explains that,

[t]he third generation of camp literature, produced primarily by Japanese Americans, was intended for a community as well as a general readership. In keeping with the movement ethos of breaking the silence that surrounded the camps, these works took on the status of testimony, favoring first-person narration. $(2015,46)$

Finally, a fourth phase of internment narratives can be found in the literary production after 9/11, in which, according to Sato,

post-redress narratives are marked by efforts to explore the inherent but previously underexamined transnational and multicultural dimensions of internment history. $(2009,455)$

Robinson points out that this fourth stage is characterized by a "multiplicity of approaches and literary forms" $(2015,46)$, and Liao labels the written production of this period as "neo-internment narratives" that "challenge the historiography of internment while revisiting and reworking the representation of internment in earlier periods" $(2020,83)$.

In relation to literary works about the Japanese American internment published over the last few years, Ahlin acknowledges Jan Assman's useful distinction between 'communicative memory' and 'cultural memory' - respectively based on "lived, embodied memories" and on "institutionalized and mediated memories" - and she notes that,

1 Similarly, Robinson reports about the challenge faced by Yoshiko Uchida in publishing her book Desert Exile (1982), "a memoir about the internment years, [which] was first written in 1966 to 1967 but turned down by some twenty publishers before the University of Washington Press published it in 1982" $(2015,49)$.

2 The important role of the Commission on Wartime Relocation and Internment of Civilians (CWRIC) in giving voice to the trauma of the internment experience cannot be overstated. See Tateishi 2020 and Pettai 2015. 
[a]t this historical moment, 70 years after the end of World War II and the Japanese American incarceration, we are in a transitional phase between these two forms of memory. $(2018,158)$

For demographic reasons, most contemporary Japanese American writers are too young to retain first-hand knowledge of the internment years, which means that they are currently keeping the collective memory of the internment alive only from a postmemory perspective (see Hirsch 2012). Nonetheless, there are still examples of narratives written in recent years by direct witnesses of the internment ordeal, as is the case with Fox Drum Bebop, written by former journalist and internment survivor Gene Oishi and described by the author himself in the Editorial Note as a "fiction based on memories [...] reimagined and embroidered in the story making" (2014). ${ }^{3}$ The protagonist of Oishi's book, 'Hiroshi', had been introduced by the author in his previous memoir, In Search of Hiroshi, as a "quasi-fictional" character who was "neither American nor Japanese, but simply me" $(1988,190)$. However, in the same memoir, Oishi had pointed out his inability to write about 'Hiroshi' and the choice of using 'Gene' as a main character, thus waiting almost three decades before writing another book that would finally portray his true self. A comparison between the two books shows that the earlier one represents a sanitized narrative of Oishi's life, presumably in response to the sociopolitical constraints of the turbulent years in which it was published, characterized by a strong political commitment by the Japanese American community as a direct consequence of the fight for an official redress from the U.S. government; at the same time, in those years Japanese Americans (as well as Asian American people in general) were also dealing with the rampant myth of 'model minority'.

Blurring the boundaries between memoir and fiction, In Search of Hiroshi and Fox Drum Bebop provide a double narrative written in two different moments - respectively during the third and fourth stage of internment narrative production - that helps reassess not only the collective memory of the internment as developed during the redress years, but also the possibility to tell stories that may go beyond essentialist assumptions about Japanese American people and their response to the internment ordeal. Focusing on Oishi's books, this essay attempts to rethink the collective memory about the internment experience and the lasting repercussions of the 'model minority' myth on Japanese Americans.

3 Other recently published internment narratives written by camp survivors are The Little Exile by Jeanette Arakawa (2017) and George Takei's graphic novel They Called Us Enemy (2019). 


\section{Gene Oishi and His Search for Hiroshi}

Born in 1933 in Guadalupe, California, Gene Oishi is a nisei (secondgeneration Japanese American) who was forced to relocate with his family, between 1942 and 1945, to the Tulare Assembly Center (CA), and later faced a detention at the Gila River War Relocation Center first, and then at the Poston Relocation Camp (both in AZ). Oishi's father had originally moved from Japan in 1903 at the age of nineteen, with the illusory dream - shared by many migrants from all over the world before and after him - of earning a fortune and then returning to his home country. Nine years after moving to the United States, Oishi's father had an arranged marriage with a Japanese woman, a picture bride ${ }^{4}$ he would eventually have eight children with, Gene being the last of them. They settled with their family in California, and ended up spending the rest of their lives in the United States, notwithstanding the harsh treatment they were forced to endure during the war.

While the internment dramatically curbed the future dreams and aspirations of Oishi's parents, the author himself managed to go on with his life, raising three children with his Jewish wife from Switzerland, Sabine, and pursuing a career in journalism with The Baltimore Sun. During his time as a journalist, Oishi inadvertently came into the national spotlight when Republican vice-presidential candidate (and future $39^{\text {th }}$ Vice President during Richard Nixon's administration) Spiro T. Agnew referred to him by using the racial slur 'fat jap', prompting a nationwide public controversy that sparked after the Washington Post reported about the episode. ${ }^{5}$

As a writer, Oishi only published two books, the aforementioned In Search of Hiroshi and Fox Drum Bebop. In the acknowledgments for the first book, the author explains how he started to write about his past and his family back in 1962, and that he kept rewriting his draft until he managed to publish the book about a quarter of a century later. The challenge with writing In Search of Hiroshi was primarily related to his inability to understand the effects of the internment experience on his life:

[a]s ruinous as the war and internment were for my parents, I did not think these events had any lasting effect on me. $(1988,9)$

4 'Picture brides' were Japanese women who moved to the United States during the first decades of the twentieth century to marry first-generation Japanese Americans. The marriage matches were usually based on photograph exchanges. See Niiya 2001, 334-6.

5 'It was not merely the epithet 'jap' that cut me, it was more the reminder that I was a member of a despised race against whom America had fought a long and bloody war" (Oishi 1988, 158). See also Witcover 2007, 43-5. 
He adds that:

Long after the war, a white friend asked me to describe the conditions in the camps. I told him the authorities would strip us naked, tie us spread-eagled to stakes in the desert, and pour honey over us so that ants would come and eat us alive. My friend laughed and protested my black humor. "Hey," I said, clawing at my shirt, "you want to see the scars?" More than two decades after the internment I still had difficulty talking about it. I did not dare look too deeply into myself to find out how I really felt about the experience, but my joke described my condition more accurately than I realized at the time. I was eaten alive in the desert, not by ants but by doubts - doubts about myself, doubts about my parents, doubts about being Japanese, and doubts about being American. I was assailed by notions that there was something wrong with me, or with my parents, or with Japanese generally. (9)

In Search of Hiroshi represents Oishi's attempt at recognizing the painful legacy of the internment while at the same time trying to heal a still-festering wound that was eating him up. According to the author himself, the attempt is only a partial success: while many years later he finally manages to write an account of the internment experience and its lasting effects on his life, Oishi explains that he is still unable to deal with the loss of innocence caused by the internment ordeal. Toward the end of his memoir, the author recounts when, in the 1980s, the National Geographic asked him to write about the Japanese in America, and he explains how he believed they had actually asked him to write about the achievements of this minority group:

[i]t was my impression that they wanted me to flesh out what social scientists have been saying for years, namely that Japanese Americans are an extraordinarily successful ethnic group, in fact a 'model minority'. (176)

As a matter of fact, In Search of Hiroshi does offer a view of the Japanese American community that implicitly supports the 'model minority' myth. In the book, Gene's family members (and by extension the whole Japanese American community) tenaciously follow the 'rags to riches' path both before and after the internment years, as demonstrated by their ability to find economic prosperity notwithstanding the complex circumstances they have to face. In addition, Oishi also describes the meekness generally displayed by the Japanese Americans by accepting the internment experience. For example:

[b]efore we left Tulare, we took our cots and blankets to a storage shed. The women passed a broom around and swept out the 
compartments. It did not seem to matter to them that the barracks had served their purpose and would be torn down as soon as we left. (52)

A few pages later, the author praises the ingrained industriousness of the Japanese American community and its ability to transform the hostile desert environment at the Gila River Camp into a more comfortable place. At first, Oishi explains that, like everyone else in the camp, his older brothers improved the bare room their family was assigned by using stolen lumber and building supplies from the storage area in the camp to craft "tables, chairs, shelves, closets, and dressers [...] which, though simple, w[ere] as fine as any you could buy" (56). Then, over time, Japanese American internees showed a deep sense of adaptability by transforming the internment camp to better suit their needs:

It was discovered that the castor plant grew quickly and well in that climate, so it was planted by individual families throughout the camp to provide greenery. Some people grew morning glories and trained them on lattices set against the barracks. Later, there were fish ponds and rock gardens. Against the summer heat, most people built coolers, a wooden frame covered with packed straw. Water would be run through the straw and an electric fan placed in the box would draw outside air through the water-soaked straw into the compartment. It had a remarkably cooling effect. From the point of view of basic physical needs, particularly after the first year when the food became minimally adequate, life was not as harsh as one might have expected. (56-7)

In his In Search of Hiroshi, Oishi tacitly employs the 'model minority' narrative to illustrate the economic success of the Japanese Americans in the United States. Nevertheless, the author also explains that, while collecting material for the above-mentioned piece commissioned by the National Geographic, instead of focusing on writing an article that would demonstrate the success of the Japanese American community, he ended up collecting interviews with many Japanese Americans from all over the United States because he was genuinely interested in learning more about them and, as a consequence, about himself. Meeting first-, second-, and third-generation Japanese Americans, often living successful lives but nonetheless still deeply affected by the internment experience, helped him understand how the different generations of Japanese Americans dealt with the internment: the first generation was relieved by the fact that the government did not want to exterminate them, but after the war they were left penniless and without any job opportunities; the second generation was devastated by the psychological trauma of the 
war and by having been considered disloyal toward the nation, while the third generation had problems understanding why their parents would be willing not only to demonstrate their patriotism at all costs by fighting in a segregated regiment like the $442^{\text {nd }}$ Battalion, ${ }^{6}$ but also to accept and behave in conformity with the 'model minority' stereotype after the war. To gather material for the article, Oishi also went and visited one of the camps he was interned at with his family, the Gila River War Relocation Center. However, he could not write the article for the National Geographic:

When I sat down, finally, to write, I could not write the article I had set out to do: an upbeat story of a plucky group of Asian Americans who, having overcome a hard and bitter past, were the Horatio Algers of our time. There was much evidence and material to support such a success story and it could have been written, but not by me. It would have deflected from the bitterness of the Japanese-American experience. I could not paint a happy face on the Japanese-American community when so many of us, especially the nisei, remained emotionally sick or crippled. (183-4) ${ }^{7}$

In this passage, Oishi recognizes the ability of the 'model minority' narrative to represent an effective tool capable of explaining how the Japanese American community, especially after the Second World War, could succeed thanks to resilience, self-discipline and hard work. However, this episode also helps to better understand at what cost did the Japanese Americans abide by the 'model minority' myth, by explaining why Oishi would want to overcome his personal challenge in writing about the internment experience and its long-last-

6 The $442^{\text {nd }}$ Infantry Regiment fought for the United States Army in Europe, and it famously became the most decorated unit in the U.S. military history. See Sterner 2015.

7 At the end of the last chapter of Fox Drum Bebop ("Uncle Sammy's Ashes"), after a discussion with a younger relative about the internment experience and the apparently counterintuitive behavior of those second-generation Japanese Americans who joined the war effort, Oishi returns to this topic by summarizing why many nisei have avoided talking about the internment years: "The Nisei couldn't talk about the camps, not only because it disturbed their self-image as Americans, but because it reminded them of a fear that ran too deep to probe. Somewhere at the core of their being, they were still terrified - afraid for themselves and afraid for their children. For all [Hiroshi] or his family knew, they'd been brought to the desert to die, to starve in a barren wasteland crawling with snakes, lizards, scorpions, and other unknown dangers. Hiroshi recalled the war propaganda: the Japanese were an evil race; they were subhuman, snarling apes, rats, vermin. Mother and many of the Issei had been convinced that they would all be killed out here in the wilderness. And though the site had turned out not to be the extermination camp they had feared, the terror and the sense of their helplessness had remained. At its most primitive level, that terror had been the unspoken shame of being Japanese. But the real threat - the worst degradation, not existentially, but spiritually - was the shame itself" $(2014,271-2)$. 
ing legacy on himself and the Japanese American community through a semi-fictional character like 'Hiroshi'. When, in 1967, the author was asked to write another article on the internment, he insisted on using this "quasi-fictional character who later became the protagonist in [his] attempt at writing a novel" (185). The author explains:

Hiroshi let me write in the third person and sustain the illusion that I was not writing about my own experiences, my own feelings, but those of this imaginary and therefore invulnerable child. (185)

Nevertheless, when he eventually had to give an account of his internment experience for the CWRIC in 1981, he was forced to use the first person, thus feeling the full impact of his own words on himself and his life:

I am an American, but an American of the Japanese race. That sentence would have struck me at one time as a contradiction in terms. I had become so used to accommodating the racist attitudes of my fellow Americans that I had become an anti-Japanese racist myself. (186)

By attempting to distance himself from his being Japanese, Oishi tried to live his whole life as if he were another person, believing that he was not to be blamed for what the Japanese had done during the war, while at the same time still feeling responsible for the atrocities committed by the Japanese Empire. Yet, by looking at himself in the mirror, he would see the face of the people he learned to despise both during and after the war, and this dissociative idea never left him. 'Hiroshi' was the only way he could find himself again as an individual person:

When I first began writing about Hiroshi, around 1965, I did so because I felt I had been cut in half by the war. It seemed to me that my American half survived, but my Japanese half shriveled up and died. Hiroshi was the last image I had of the whole child. He was the child who ate misoshiru and shouted "banzai!" to the Emperor on his birthday, listened to the Lone Ranger on radio, and followed the adventures of Batman in the comic books. He was neither American nor Japanese, but simply me. (190)

The final lines of In Search of Hiroshi set the stage for what Oishi will write about in Fox Drum Bebop. The author states that his goal had been "to clear away the fear and confusion" related to his search for 'Hiroshi': 
Like a good detective, I needed to determine first when and where I had lost him. I have done that now, and the search for Hiroshi can continue. (190)

\section{$3 \quad$ Finding Hiroshi Three Decades Later}

On the inside flap of In Search of Hiroshi, it is stated that:

Gene Oishi shatters the glossy image of the Japanese Americans as a well-adjusted and contended 'model minority'. (Oishi 1988)

Yet, rather than openly doing so, it might be more accurate to state that, in his 1988 memoir, the author only indirectly opposes the 'model minority' myth by focusing almost exclusively on how the trauma of the internment affected himself and his personal life as a Japanese American. As a matter of fact, it is only in his more recent work Fox Drum Bebop that Oishi systematically challenges stereotypical assumptions about Japanese Americans as a 'model minority' by challenging the very idea of a unified representation of the Japanese American experience during and after the internment.

Oishi's In Search of Hiroshi was written as a first-person memoir that would chronologically progress from Pearl Harbor and the internment to the 1980s, focusing on Gene Oishi's point of view, as a witness and at the same time a victim of the events described. The writing style adopted by Oishi would work well as both a journalistic article and a testimony similar to those collected for the redress, and in fact the book seamlessly includes excerpts of an article he previously published in The New York Times Magazine (Oishi 1985), also quoted in Congress by Senator Daniel Inouye (HI) on May 2, 1985, to support the redress (Inouye 1985). ${ }^{8}$ In the case of Fox Drum Bebop, Oishi decides to change the narrative style the book is written in: while there still is a predominant point-of-view character, Hiroshi, Fox Drum Bebop is in fact drafted as a short-story cycle based on fourteen independent short stories in the third person, all of which are more or less unified either around the theme of the internment or in relation to the lives of Hiroshi and his family from the war years up to the 1980 s. ${ }^{9}$ As a

8 Sen. Inouye, in supporting the implementation of recommendations made by the CWRIC regarding the internment of Japanese Americans, asked for Oishi's article, titled "The Anxiety of Being a Japanese-American", to be included in the Congressional Record. Parts of the same article were also incorporated by Oishi himself in chapter 19 of In Search of Hiroshi.

9 In order to define the short-story cycle and its structural discontinuities, Nagel explains that "a central point is that in the short-story cycle each component work must 
direct consequence of this narrative choice, Oishi's Fox Drum Bebop constitutes a book capable of offering a plurality of voices and perspectives, overcoming the idea of a consistent and non-contradictory recollection of past events evolving around a single character, as is the case with In Search of Hiroshi. It might be argued that the unity effect obtained by Oishi in the 1988 book was a direct result of the need to unequivocally denounce the personal experience of a victim of the internment and its effects on him and his family, with the internment embodying the epicenter of all the racism and injustice endured by the Japanese American community. However, it is also possible to state that a collateral effect of that choice is the depiction of an essentialized portrait of the Japanese American community where differences among its members end up being minimized, with the result of portraying a more homogeneous group of victims and thus implicitly reinforcing both the idea of the 'model minority' and the necessity of the redress process. On the other hand, Gene Oishi's Fox Drum Bebop seems to deliberately undermine any attempt at creating a binary system opposing a victimized Japanese American community to the hegemonic mainstream. As Lisa Lowe posits, "heterogeneity, hybridity, and multiplicity" can be used "to disrupt the current hegemonic relationship between 'dominant' and 'minority' positions" (1991, 28), and this is precisely what Oishi achieves in Fox Drum Bebop.

The first short story from Oishi (2014) sets the tone for the whole collection. Emblematically, the story takes place in the years 1940-41, right before Pearl Harbor and the internment, that is, at a time when Oishi can still identify Hiroshi as a "whole child". ${ }^{10}$ The title of the story, "The Okie", refers to Tex, a boy from Texas who has recently moved to the fictional town of Hacienda, California, where Hiroshi lives:

stand alone (with a beginning, middle, and end) yet be enriched in the context of the interrelated stories. In contrast to the linear development of plot in a novel, the cycle lends itself to diegetical discontinuities, to the resolution of a series of conflicts, to the exploration of a variety of characters, to the use of a family or even a community as protagonist, to the exploration of the mores of a region or religion or ethnic group, each story revealing another aspect of the local culture. One of the most fascinating aspects of the contemporary fictional cycle is that writers from a wide variety of ethnic groups have used the form for the depiction of the central conflicts of characters from their own race or nationality. As 'American' narratives, these stories often involve the process of immigration, acculturation, language acquisition, assimilation, identity formation, and the complexities of formulating a sense of self that incorporates the old world and the new, the central traditions of the country of origin integrated into, or in conflict with, the values of the country of choice" $(2001,15)$.

10 Conversely, in the case of In Search of Hiroshi, little is told about the author's first years of life before the internment, except the fact that he and his family used to live in a hybrid environment between Japanese and American culture: "I had samurai and cowboy heroes. I felt at home in both American and Japanese settings and slid easily from one language to the other" (Oishi 1988, 38). The author then adds that: "I felt no conflict within myself between American and Japanese things, but I was made aware very early of the tension between America and Japan" (38). 
The boy was barefoot. He had dirt on his face. His overalls were patched and shredded. His dirty blond hair covered his eyes like a sheep's dog.

Hiroshi thought he might be an Okie.

[...]

"You an Okie?" Hiroshi asked.

"Naw, I ain't no Okie. We come from Texas. You can call me Tex if you like. You Chinese?"

"Japanese!" Hiroshi said, clenching his fists.

The two boys stood at arm's length, silently taking each other in. (Oishi 2014, 1)

While the two boys immediately try to categorize each other in terms of racial and socioeconomic labels (and Oishi highlights the obvious impossibility to use such overgeneralizing labels in any meaningful way), they become friends and quickly overcome any essentialist view of each other. However, Hiroshi's family does not accept such a friendship, because they see themselves as of higher social status. When Hiroshi's father learns about his youngest son spending time with "the white boy" (5), he harshly scolds Hiroshi:

Father's voice was like thunder striking the earth. "You are Japanese", Father said. "Such boys are below you. What if someone saw you? What would people think? It's a black mark on the family". (5)

What is happening in this short story is the enactment of the same racism - this time from a Japanese American family toward a kid and his migrant family from Texas - that will very soon affect Hiroshi himself and his family, thus highlighting the systematic presence of racism and prejudice in pre-war California.

While the entire community sees Tex with prejudicial eyes - "The white children persisted in calling Tex an Okie and would have nothing to do with him. Even the teachers were cold toward him" (Oishi 2014, 6) - it is the local Sheriff MacAffrey who expels Tex and his mother, a former schoolteacher, from the railroad shack they were occupying since they had moved to Hacienda. Hiroshi lives in one of the largest and nicest houses in town (located at "Hidalgo Street" - i.e. "Gentleman Street"); on the other hand, Tex and his mother live in a shack that "was so small that most of the family's possessions had to be piled on top of one another to fit" and where "[t]wo small beds that had been squeezed together took up nearly half the space" (9). Sheriff MacAffrey seems to have treated recurring occupants of that shack (which was originally meant for storing railroad maintenance equipment) in different ways: 
Other families had lived in the shack before, but none had lasted more than few weeks before Sheriff MacAffrey kicked them out. After the last family was evicted, Tex and his parents moved in. Sheriff MacAffrey didn't bother them for some reason - maybe because Tex's father left soon thereafter, leaving Tex and his mother all alone, or maybe because he was busy with other things. (8)

Nevertheless, one night Hiroshi sees the sheriff while he is threatening the boy and his mother to force them to leave the place as quickly as possible:

"Twenty-four hours!" he said, "You got twenty-four hours. That's it! This time, I mean it. I'm fed up with you goddamn Okies". (14)

The short story ends when Hiroshi goes home with a hidden awareness that it would be the last time he heard about Tex and his mother.

Sheriff MacAffrey reappears in the third chapter of the book, titled "Kurombo Boy" and set during the first months after Pearl Harbor. With the relocation approaching, MacAffrey

wanted to make sure that the evacuation went smoothly, that no one harmed [Hiroshi's family] or gave them any trouble. (38)

He praises the industriousness and economic success of the Japanese Americans:

"You folks have done pretty well in this country. I remember when I was a boy in Hacienda - that was a long time ago - and you people were working in the beet fields like Mexicans, doing stop labor". (39)

However, what the sheriff really wants from Hiroshi's family is a bribe, and they end up giving him one hundred dollars.

It is worth pointing out that many details in this chapter are exactly the same as in In Search of Hiroshi: for example, the fact that Hiroshi was asleep when his father was taken by the FBI, or the fact that the boy focused his attention on the cutting of the house's telephone line ${ }^{11}$ or else the fact that his mother would justify Hiroshi's

11 As it usually happens with people who live through dramatic events that affect the historical memory of a nation, Oishi vividly recalls, in In Search of Hiroshi, the hours before and after the bombing of Pearl Harbor. Soon after the attack from the Japanese Army, his father was arrested for allegedly being a leader in the Japanese American community, and the family would not be able to see him again for about two years: "I slept through my father's arrest. [...] The FBI men had cut the cord of the receiver before they left so we would not be able to tell anybody that they were coming. The FBI 
dark skin as a consequence of her having drunk too much tea during the pregnancy. ${ }^{12}$ Based on the similarities between the events described in this book and the content of In Search of Hiroshi, readers might wonder to what extent Oishi's 2014 book should be exclusively considered a work of fiction. However, since the author himself gave this label to Fox Drum Bebop, it might still be argued that all the changes made in the book compared to In Search of Hiroshi are solely based on the author's imagination. Yet, it is hard to avoid any comparison between what happens to Hiroshi's family in the short story "Kurombo Boy" and what is described in the first short story of the book, "The Okie", since in both cases Sheriff MacAffrey seems to be taking advantage of his position as a law officer against targeted minorities. Police corruption underscores a similarly subaltern condition between Japanese Americans and Dust Bowl refugees, and the presence of the 'fiction' label given to Fox Drum Bebop, together with the similarities with In Search of Hiroshi, suggest that such a despicable situation might have really happened, including the racist attitudes expressed by Hiroshi's family against a white boy from Texas.

Another short story from Fox Drum Bebop whose protagonist is from a different ethnic group is "Ramon", where the eponymous character is a Mexican American boy that Hiroshi meets right after the end of the war upon his return to Hacienda. The two boys meet at school, and the Mexican American boy

gave [Hiroshi] a slight push with an open hand and, looking directly into his eyes, said: "You dirty yellow Jap". (119)

However, soon after this rather abrupt encounter the two boys become friends, also due to them being both outcasts from minority groups and regularly mistreated or simply ignored at school. Nonetheless, Hiroshi's parents taught their son to be wary of Mexican people, and they do not approve of Hiroshi's new friend.

One day, Ramon tells Hiroshi that, according to his older brother Tony, his family used to work for Hiroshi's father:

cutting the telephone cord had more of an immediate emotional impact on me than their arresting my father. It was tangible evidence that the American government saw us as enemies" $(1988,40)$.

12 "When I was a child, my mother was apologetic about my dark complexion. 'I drank too much tea when I was pregnant with you,' she would say" (Oishi 1988, 29). Note also that the title of the short story "Kurombo Boy" includes the Japanese equivalent of the n-word, and it refers to the racial slur that Hiroshi's older sister would use to taunt the boy. 
"Tony says your father was a cheap guy, made him and my mother work and didn't pay them nothin'. They had to shovel shit out of the stable every day and your old man never paid them one centavo". (129)

When Hiroshi asks his mother about Ramon's family, she starkly defends her husband:

"How can you say such a thing? [...] Your father did more for the people of Hacienda than anybody. Only a few ungrateful people whispered lies about him". (131)

She then recalls that Hiroshi's family used to be the wealthiest one in town before the internment, and that, given the current situation after the war, it is unfair to accuse Hiroshi's father of any wrongdoing:

"Don't trouble your father with trivialities about a lowly Meshikan [i.e. Mexican] woman!". (131)

Still, Hiroshi's mother never really denies her husband's mistreatment of Ramon's family and, by comparing the events described in this short story with the ones told in "The Okie" and "Kurombo Boy", it is clear that the author is writing about the relationships among different ethnic groups as unequivocally unfair whenever one of the groups involved happened to be in a position of economic/social/political advantage toward the other minorities, thus challenging any simplistic narrative based on the dichotomy 'Japanese Americans vs others'.

Hiroshi's character is also rather complex: compared to how Oishi portrays himself in In Search of Hiroshi, Hiroshi is more ambivalent and less positive, a flawed character who will eventually make the same mistakes made by those who incarcerated him during the war. For example, Fox Drum Bebop contains an episode where one night, at the end of a show organized by internees at the camp, Hiroshi throws stones against the crowd. While similar memories can be found in In Search of Hiroshi, in the case of Fox Drum Bebop Hiroshi ends up hurting a young and innocent girl:

After the movie, as people began to disperse, Hiroshi picked up a rock and hurled it into the crowd.

Shouts echoed from down below, about where the stone would have landed. Hiroshi ran down the hill to where the commotion was and looked around cautiously. A man had picked up a small girl, four or five years old, and was carrying her. Someone had tied a handkerchief around her head. She was crying, her face glistening with blood in the moonlight. "What happened?" people were saying. "She's okay, she's okay", the man said. "Get a doctor!" 
someone shouted. Hiroshi edged away from the crowd, and when he was far enough away, he broke into a run. When he reached his barracks, his stomach began to churn, and he vomited. (47)

The throwing of the rock against a crowd of internees in Fox Drum Bebop represents the symbolic equivalent of internment conceived as a tragic case of friendly fire involving Americans versus other Americans. In addition, the victim of this unnecessary and cruel attack by Hiroshi ends up being a four- or five-year-old girl, a quintessentially innocent person who is nonetheless interned for her being of Japanese ancestry. ${ }^{13}$

While other misdeeds might be related to hunger and necessity - as when Hiroshi is caught by his mother stealing potatoes during the internment (63) - later in the book, while being a university student in the chapter titled "Urashima", Hiroshi refers to a German friend of his then girlfriend as a 'Nazi' (201) for no apparent reason, thus applying the same prejudicial attitude that years before put his family and the rest of the Japanese American community in internment camps. ${ }^{14}$ Another chapter, "Rewrite", focuses almost entirely on Hiroshi's issues with alcohol. During the story, Hiroshi loses control of his drinking problem, to the point of risking his marriage and his job at The Baltimore Sun, while allowing his dog to freely assault or even kill other dogs in the neighborhood. A more problematic and multifaceted representation of the main character of Fox Drum Bebop compared to In Search of Hiroshi entails that Oishi tries to describe

13 In Fox Drum Bebop, Oishi merges two different recollections from his 1988 memoir. In the first memory, the author confesses to having thrown pebbles at a crowd of internees after a show held at Tulare Camp: "When the show was over and the people began to file out of the grandstand, another boy and I took pebbles and hurled them into the crowd. I didn't know why I was doing this, but it gave me a terrific feeling of release. Two women walked by and one of them said, 'Oh look. Look at the bad boys'. But they did nothing to stop us and we kept throwing. When I look back on the incident, it seems to me that it was my way of bombing all Japanese. [...] A few months later, at the camp in Gila, Arizona, I would do what amounted to the same thing" (1988, 50-1). At the end of the same page, Oishi also recalls the following memory: "At Gila, I once saw a teenage boy hurl a rock through a mess hall window. He did not seem to be aiming at anybody, but he did hit a little girl. I saw blood streaming down her face as two men rushed out of the mess hall and chased the boy across a firebreak. Midway across the field, one of the men managed to kick the boy's feet from under him and sent him sprawling to the ground. As they led the boy back to the mess hall, one of the men cuffed him on the head. I never found out why the boy did what he did, but I assumed he had no specific reason for throwing the rock; he just wanted to do something bad, just as I had wanted to do something bad when I threw pebbles into the crowd in Tulare" (512). In the artistic reimagining of these two memories in Fox Drum Bebop, it is Hiroshi himself who hits the young girl and, while the unnamed boy in In Search of Hiroshi is caught and presumably punished for his reckless deed, Hiroshi manages to run away unpunished, showing only belated remorse by feeling nauseous and vomiting.

14 "Hiroshi couldn't explain why he had said such a stupid thing. The memory of it made him cringe" (Oishi 2014, 201). 
the limits of a character like Hiroshi, who would not simply be making mistakes in his life that can all be traced back to the trauma of the internment, but who is also inherently flawed and consequently more human and less stereotypically close to a character - like Oishi's selfportrayal in In Search of Hiroshi - that would, by implication, reinforce the idea of the Japanese American people as a 'model minority'.

Some of the short stories in Fox Drum Bebop more directly address political issues related to the internment, thus highlighting how complex the situation was during the war years. Two short stories, "Quandary" and "Uncle Sammy's Ashes", describe the different political attitudes of the Japanese American people during the internment, starting from two of Hiroshi's brothers - one of whom, Mickey, enthusiastically joins the U.S. Army and becomes a decorated soldier, while the other, Yukio, is a $k i b e i^{15}$ who spent many years in Japan in order to get an education, who cannot speak English well and is enraged with the government due to the injustice of the internment. The quandary one of the aforementioned short stories' title refers to is the feeling of hopelessness experienced by one of the internees, Mr. Nakashima, characterized as a Marxist political activist who expresses a radical thinker's point of view, denouncing both the foolishness of a small country like Japan in starting a war against the United States and the injustices inflicted upon Japanese Americans by the U.S. government. ${ }^{16}$ Sammy, another brother of Hiroshi's who is wheelchair-bound because of polio, explains to his younger brother why Mr. Nakashima eventually decided to kill himself in the desert (a few months later, Sammy would choose to end his own life as well, in the same desert). According to him:

Mr. Nakashima had nothing left to live for. He thought his life was finished. He knew Japan was losing the war. He didn't really want Japan to win, but he didn't want America to win either. He was in a quandary. [...] A quandary, Hiro, is when there's no right answer, when there's no place to go, when there's no hope, no future. (110-1)

15 The Japanese word kibei refers to second-generation Japanese American people who were sent to Japan for a number of years to attend school and get a Japanese education. Usually, once they returned to the United States, the kibei struggled with reintegrating into society, also due to linguistic barriers (see Niiya 2001, 243).

16 Mr. Nakashima, in an apparently self-deluded attitude, criticizes the decision made by the U.S. government in choosing and then arresting the allegedly most dangerous members of the Japanese American community (like Hiroshi's father) immediately after Pearl Harbor: "'My life has been devoted to bringing down the capitalist system', [Mr. Nakashima] mused, 'and now I sit here in the middle of a desert, helpless and forgotten. When the war started, agents of American capitalism ignored me. Me! Who had devoted my life to bringing them down! Instead, they arrested Buddhist priests, Japanese - school teachers, shopkeepers, businessmen, rich farmers like your father. They arrested the bourgeoisie - pitifully harmless people. They arrested their own kind!'” (Oishi 2014, 105). 
The uninhibited Mr. Nakashima character represents, in Oishi's novel, the role of the 'wise fool' who would catch readers off guard by offering a complex but revealing perspective on the war and the internment, thus crushing any effort at oversimplifying the issues at hand and essentializing the Japanese American community.

A brilliant attempt at explaining the reasons behind the irrational choices that brought the U.S. government to start the internment can be found in the short story titled "The Emperor's Birthday". Set in May 1941, the story depicts the celebrations for Emperor Hirohito's fortieth birthday held in Hiroshi's town, and involving the boy's whole family in different capacities. The chapter starts by acknowledging that, since the birthday happened to be on a Tuesday,

the local farmers were still busy with their spring plantings, and store owners in the area were unwilling to lose a day's worth of business by closing their shops in the middle of the week. (18)

This remark frankly demonstrates how the Emperor's birthday would only have a secondary importance for the local Japanese American community compared to their regular business activities. As a consequence, the celebration gets postponed to the following Sunday. The event includes a religious ceremony held by a Buddhist priest who fails to mention the Shintoist (as well as nationalist) belief in the divine origin of the emperor, and several speeches given by notable members of the community, including Hiroshi's father, who not only provides the event organizers with the emperor's portrait to be put on display during the celebration, but also invokes the 'Yamato spirit' during the event:

"The Yamato spirit is what drove us", Father said. "We came over in steerage, eating wormy rice and drinking stagnant water. We made our way in this strange land by washing dishes, sleeping on kitchen floors, working the hakujin [i.e. white people]'s fields from dawn to dusk. But we survived; we rose because of what we are and what we will always be, the people of Yamato". (20)

However, the narrator quickly points out how Hiroshi is perfectly aware that his father's speech is untrue, since the man only spent limited time in the U.S. doing physical labor, which means that he never really experienced the harsh life mentioned in his words. Hiroshi's father's phony speech is followed by the singing of the national anthem, which Hiroshi knows well - even though he does not understand its words - and by a vigorous shouting of the word "Banzai!" by the 300 people gathered at the local Young Men's Association Hall. Among them, the children are especially excited to shout that word: 
Like all the other children, Hiroshi joined enthusiastically in the group salutation, even though he had no idea what it meant. The one thing he and all the other children knew for sure was that the gesture marked the end of the ceremony. (20-1)

The big event of the day is a Kabuki performance organized by Hiroshi's father, who plays the role of Sato Tadanobu, a samurai loyal to the legendary Japanese Lord Minamoto Yoshitsune. The story follows Tadanobu while on a mission to bathe Yoshitsune's flute with the blood of a virgin in order to use it as a weapon against the enemies; however, though Tadanobu cannot help falling in love with the woman, he is still loyal to his Lord and, driven by his sense of duty, he decides to complete his mission by killing her with a sword. The successful performance highly fascinates Hiroshi; more specifically, he is impressed by the blood he sees on Tadanobu (i.e. his father)'s sword, until the spell is broken once his mother reveals the blood to be nothing but ketchup. At the end of the chapter, Hiroshi goes to bed and keeps thinking about the events of the day:

It took a long time for Hiroshi to fall asleep. The horrific image of his father resplendent in full samurai armor was still fresh in his mind. But as it turned out, the sword his father had wielded so fearsomely was counterfeit and smeared not with blood but with tomato sauce. The armor was no doubt also phony, probably made of bamboo, not steel. That was just the sort of trick a fox would play. And it had all taken place as part of the celebrations for a birthday that was not the actual birthday of an Emperor who wore steel-rimmed glasses and looked more befuddled than divine. Shig had even made fun of the Emperor as he crammed hi[s portrait] into the trunk of his car like a piece of worn-out luggage. (31-2)

What seems to be described here is a mocking allegory of what the government erroneously believed would be the inevitable betrayal of the United States by the Japanese Americans: Hiroshi's father/ Tadanobu, though in love with the woman he is supposed to sacrifice (who embodies the United States as a land of opportunity and economic prosperity), would always remain loyal to Yoshitsune (i.e. the emperor and by extension the Japanese Empire) and is ready to transform himself into a merciless killer in order to serve his Lord. Considering how the same chapter also points out that Hiroshi's father has contributed to the Japanese War Fund, and that in the next one ("Kurombo Boy") he is said to have toasted to the bombing of Pearl Harbor with sake, it is clear how Oishi has developed a character who acts as a Japanese patriot. Nonetheless, during a conversation about Hiroshi's father's choice to bring his first son Yukio back from Japan without allowing him to finish his studies at the most 
prestigious academic institution in Japan, Tokyo University - thus preventing him from being conscripted in the Japanese Army - it is also pointed out that Hiroshi's father "is a patriot [...] but what he cares about more is his family" (23). Indeed, by reading Fox Drum Bebop, it is obvious that both Hiroshi's father's immediate arrest after Pearl Harbor and his prolonged detention are solely based on wartime hysteria, since such a political move has nothing to do with breaking the law or betraying the country in an alleged effort to help the Japanese as a fifth column in the war against the United States. ${ }^{17}$

\section{A New Internment Narrative Against the Long-Lasting 'Model Minority' Myth}

Comparing Fox Drum Bebop to In Search of Hiroshi helps understand how Oishi's description of his own past in the 1988 memoir complies with the 'model minority' myth even though his original goal was to denounce the harrowing experience of the internment and the challenges faced after the end of the war, focusing on himself as a representative member of the Japanese American community. The concise but complete definition of Asian Americans as a 'model minority' offered by Kim seems like an apt description of In Search of Hiroshi's characters:

Asians are supposed to be restrained, humble, and well-mannered, a people who respect law, love education, work hard, and have close-knit, well-disciplined families. Above all, they are praised for not complaining about or protesting against difficulties: they may have problems, but they really do not mind these, and they 'take care of their own' instead of burdening 'Americans' with their

17 The same kind of wartime hysteria can still be read in right-wing books such as the highly controversial In Defense of Internment (2004), written by conservative political commentator Michelle Malkin as an attempt at justifying the illegal detention of Muslim people after $9 / 11$ by comparing it to a revisionist account of the Japanese American internment during the Second World War. In her book, Malkin specifically writes about meetings that are not so dissimilar from the one described in Oishi's "Emperor's Day" as proof of the alleged criminal intent of Japanese Americans: "In the summer of 1937, a group of fifty ethnic Japanese living in and around San Francisco established the headquarters of the Japanese Military Servicemen's League. [...] The league had grown to more than ten thousand members, according to intelligence officials. Members included both Issei and Nisei. They paid dues to support the Japanese Army and Navy War Relief Fund. [...] League chapters hosted warmongering Japanese speakers and showed propaganda films to raise funds. Meetings began with the singing of the Japanese national anthem and ended with exclamations of loyalty to the emperor. Near San Francisco, members pledged support 'for our emperor, our country, our race, and our posterity'. A San Diego meeting ended with three rousing cheers of 'Long Live Japan!'” $(2004,18)$. 
needs by seeking government aid and welfare assistance. Most important, they do not 'take themselves too seriously'. $(1982,177)^{18}$

The 'model minority' myth is implicitly used in In Search of Hiroshi as an additional rhetorical tool to further convince mainstream readers of the truth value of the accusations against the government in relation to the redress, as if the constant infringement of constitutional rights against the Japanese American community during the war was not enough proof for their request for justice and reparation.

However, the still pernicious 'model minority' myth survived well after the end of the redress years, and it is still highly popular in the United States. With Fox Drum Bebop, Oishi tries to reimagine his first book by addressing the need to both once again denounce the injustice of the internment and reclaim the freedom for Hiroshi and all the other characters in his 2014 novel to go beyond any essentialist view of Japanese Americans as a 'model minority'. Indeed, Oishi himself points out, in the afterword to Fox Drum Bebop, that the book continuously defies the readers' prejudicial expectations about Japanese American people:

When reading a chapter from Fox Drum in a writers' workshop, a woman objected to the 12-year-old Hiroshi shouting, "That's bullshit", to his friend. A nice Japanese boy would never use such a word. At another workshop, readers objected to a depiction of a raunchy Japanese couple in the camp. When someone the next compartment over complains of the sexually explicit noises coming through the walls, the man says, "What else but nookie in this goddamn place." Would a Japanese American be so coarse and common? Another reader was upset because Hiroshi's father did not pay a Mexican woman for cleaning out his stable. A Japanese would honor his debts. Others thought the father's patriotic love of Japan

18 As Lee reports, in the late twentieth century "[n]ewspapers and magazines routinely praised Asian Americans for displaying the attributes most prized by American capitalism and its emphasis on achievement. In 1984, Newsweek reported that Asian Americans packed the honor rolls of 'some of the country's most highly regarded schools' and routinely outscored other racial groups on the math portion of the Scholastic Aptitude Test (SAT). Fortune magazine's description of Asian Americans as 'America's Super Minority' explained that Asian Americans were 'smarter and better educated and ma[d]e more money than everyone else' partly because of their upbringing, but also because of genetics. 'Asian Americans,' the magazine flatly declared, were simply 'smarter than the rest of us.' [...] popular media discourse about the Asian American model minority in the 1980s was an effective way to compare Asian Americans to other minorities. [...] The intent was to delegitimize claims of systemic racism and discrimination in the United States as the cause for educational and income gaps between whites and nonwhites and promote the idea of a color-blind society, in which opportunity was equal to all. If Asian Americans could succeed, proponents of the model minority discourse argued, why couldn't others?" $(2019,257-8)$. 
made him a zealot. Reverence for the Emperor, flying the Japanese flag from a mountain top, a leftist radical Sansei [i.e. third-generation Japanese American] who calls the revered 442nd Regimental Combat team cannon fodder - these were nothing short of blasphemy. In my private life, a Sansei writer with whom I was corresponding was shocked when I wrote in one of my letters that I loved Japan. He thought I was insane, and our correspondence ended shortly thereafter. (278)

At this point it is almost unnecessary to highlight that none of the examples above was originally included in In Search of Hiroshi; conversely, all of them are intentionally part of Fox Drum Bebop in order to challenge stereotypical assumptions about Japanese American people as a 'model minority'. In discussing the recent developments in post-postmodern fiction, Nicholas Frangipane analyzes some contemporary novels written between the end of the twentieth and the beginning of the twenty-first century where the same stories are told more than once, thus allowing authors to offer metanarrative reflections on the relationship between reality and fiction:

Many novels that show us two versions of the [same] story place their focus on showing us that fiction can lead to a deeper understanding of events, to a sort of truer truth than a recounting of the actual facts would allow. $(2019,50)$

By using The Things They Carried (1990) by Tim O'Brien as an example, Frangipane argues that

storytellers manipulate certain details to make particular points, and that a true story isn't always limited to what happened. (57)

By borrowing from the philosopher of mind David Herman the concept of 'qualia', which represents "what it feels like" (29), Frangipane uses the episode of the alleged murder of a young man, twice-told by the character of Tim O'Brien in The Things They Carried, to explain that, while contemporary authors are well aware of the fact that it is arguably impossible to write a true story in a genuinely objective way, fiction can still represent a powerful opportunity to convey a different kind of truth:

[Tim O'Brien] did not really throw the grenade, as he narrates earlier, but he feels a strong sense of guilt, as strong as if he had thrown that grenade, and that is why he must tell the story in which he throws it, because it is the only way he can make us see him as guilty, as guilty as he feels. The fictional story is the only way to get to what the situation actually felt like, what I have 
been calling the qualia. "I want you to feel what I felt," he writes, "I want you to know why story-truth is sometimes truer than happening-truth". (179)

While, technically speaking, In Search of Hiroshi and Fox Drum Bebop are two separate publications, given the striking similarities in terms of described events they can also be considered two versions of the same story. Consequently, according to the example offered by Frangipane, it is possible to imagine that, in the case of Gene Oishi/ Hiroshi's throwing of rocks toward a crowd of Japanese American internees, Oishi never really hurt any girl, but it can nonetheless be argued that the author is trying to explain through Hiroshi, in Fox Drum Bebop, how he did feel as if he had hurt an innocent little girl with his reckless act. As a consequence, Oishi's 2014 book can be considered a 'truer' version of his previous memoir which goes beyond a journalistic and factual account of the events belonging to the author's life in order to describe how he, his family, and the Japanese American community experienced the internment and were condemned to deal with two different kinds of dehumanization: as enemies of the country first and as members of the 'model minority' myth later. Therefore, the existence of a strong intertextuality between In Search of Hiroshi and Fox Drum Bebop allows the readers of the second book to rethink the collective memory of the internment as portrayed in Oishi's previous account while acknowledging that the greater chronological distance from the narrated events does not necessarily produce a higher degree of inaccuracy or rather a more limited knowledge of the internment and its effects. As a matter of fact, Fox Drum Bebop seems to effectively represent a new, deeper perspective on the internment experience which implicitly takes into consideration the recent challenges faced by the Japanese American community after the redress years, from the discussions created around the similar situation experienced by Muslim Americans in the aftermath of 9/11 (see Boch 2004; Tateishi 2020, 355 ff.) to the recent pro-internment statements by President Donald Trump (see Bromwich 2016; Lee 2016) and the backlash against Asian Americans due to the Covid-19 pandemic (see Edmondson 2021), which ultimately led to the Atlanta spa shootings of March 16, 2021 (see Egan 2021).

Gene Oishi's Fox Drum Bebop thus further enriches the collective memory of the internment by offering fictional accounts with the goal of describing terrible events and experiences in a more effective and 'truer' way. Thanks to his use of the 'fiction' label in Fox Drum Bebop, Oishi is able to denounce the cruelty of a society in which different ethnic groups fight against one another for sheer economic profit, where police officers harass poor people and take advantage of a traumatic event like the internment for personal gain, where the characters may lack any redeeming qualities yet still deserve repara- 
tion for the mistreatment they were subjected to during the war, and where an ethnic group is stripped not only of the right to celebrate its own culture, but also of the possibility to voice its discontent against the injustices perpetrated by the U.S. government. In other words, Oishi's Fox Drum Bebop succeeds in leaving behind the claustrophobic condition generations of Japanese Americans were confined to in order to abide by the 'model minority' stereotype, while telling a universal story of injustice where vivid characters continuously contradict any expectations about their having a humble and submissive behavior. By doing so, Oishi creates 'truer' Japanese American characters who are finally able to defy the very idea of offering a reassuring image of themselves as a 'model minority' for a mainstream readership and its relentless need to categorize and label people with the goal of disempowering them.

\section{Bibliography}

Ahlin, L. (2018). "Whose Memory? Contemporary Narratives of the Japanese American World War II Internment". Rudaitytè, R. (ed.), History, Memory and Nostalgia in Literature and Culture. Newcastle upon Tyne (UK): Cambridge Scholars, 157-72.

Arakawa, J. (2017). The Little Exile. Berkeley (CA): Stone Bridge Press.

Boch, A. (2004). 9066 to 9/11. Japanese American National Museum (JANM). https://www.youtube.com/watch?v=b4k7Mn-4W40.

Bromwich, J.E. (2016). “Trump Camp's Talk of Registry and Japanese Internment Raises Muslims' Fears”. The New York Times, Nov. 17. https:// www.nytimes.com/2016/11/18/us/politics/japanese-internment-muslim-registry.html.

Edmondson, C. (2021). “Asian-American Lawmakers Call Out Racist Language: 'I Am Not a Virus'”. The New York Times, Mar. 18. https://www. nytimes. com/2021/03/18/us/politics/asian-politicians-racism.html.

Egan, L. (2021). "Biden, Harris Extend Support to Asian Americans in Wake of Atlanta Shootings". NBC News, Mar. 19. https://www.nbcnews.com/ politics/white-house/biden-harris-visit-georgia-shiftsfocus-after-atlanta-shootings-n1261491.

Frangipane, N. (2019). Multiple Narratives, Versions and Truth in the Contemporary Novel. New York: Palgrave. https://doi.org/10.10०7/978-3-०3०32193-2.

Herman, D. (2009). Basic Elements of Narrative. Malden (MA): Wiley-Blackwell. Hirsch, M. (2012). The Generations of Postmemory. Writing and Visual Culture After the Holocaust. New York: Columbia University Press.

Inouye, D. (1985). "Section 310 - Separability of Provisions". Congressional Record, 131(8), 10271-4.

Kim, E.H. (1982). Asian American Literature. An Introduction to the Writings and Their Social Context. Philadelphia (PA): Temple University Press.

Lee, E. (2019). America for Americans: A History of Xenophobia in the United States. New York: Basic Books. 
Lee, T.G. (2016). “Trump Supporter: Internment 'Precedent' for Muslim Registry to 'Protect America'". NBC News, Nov. 17. https://www.nbcnews.com/ news/asian-america/trump-supporter-cites-internmentprecedent-muslim-registry-n685131.

Liao, P. (2020). Historical Fiction and Alternate History Fiction. Transnational and Multidirectional Memory. New York: Palgrave. https://doi. org/10.1007/978-3-030-52492-๑.

Lowe, L. (1991). "Hetereogeneity, Hybridity, Multiplicity: Making Asian American Differences". Diaspora: A Journal of Transnational Studies, 1(1), 24-44. https://doi.org/10.1353/dsp.1991.0014.

Malkin, M. (2004). In Defense of Internment. The Case for "Racial Profiling" in World War Il and the War on Terror. Washington, DC: Regnery Publishing.

Nagel, J. (2001). The Contemporary American Short Story Cycle. The Ethnic Resonance of Genre. Baton Rouge (LA): Louisiana State University Press.

Niiya, B. (ed.) (2001). Encyclopedia of Japanese American History. Updated Edition. New York: Facts on File.

O’Brien, T. (1990). The Things They Carried. New York: Houghton Mifflin.

Oishi, G. (1985). "The Anxiety of Being a Japanese-American”. The New York Times Magazine, Apr. 28.

Oishi, G. (1988). In Search of Hiroshi. Tokyo: Charles E. Tuttle Co.

Oishi, G. (2014). Fox Drum Bebop. New York: Kaya Press.

Okada, J. (1957). No-No Boy. Tokyo; Rutland (VT): Charles E. Tuttle.

Okada, J. (1976). No-No Boy. Seattle; San Francisco: Combined Asian-American Resources Project.

Pettai, E. (2015). "Interactions Between History and Memory: Historical Truth Commissions and Reconciliation". Kattago, S. (ed.), The Ashgate Research Companion to Memory Studies. Farnham (UK): Ashgate Publishing, 237-50.

Robinson, G. (2015). "Writing the Internment”. Parikh, C.; Kim, D.Y. (eds), The Cambridge Companion to Asian American Literature. New York: Cambridge University Press, 45-58.

Sato, G.K. (2009). “Japanese American Internment”. Huang, G. (ed.) The Greenwood Encyclopedia of Asian American Literature. London: Greenwood, 451-6.

Sterner, C.D. (2015). Go For Broke: The Nisei Warriors of World War II Who Conquered Germany, Japan, and American Bigotry. Clearfield (UT): American Legacy Historical Press.

Takei, G. (2019). They Called Us Enemy. Marietta (GA): Top Shelf Productions.

Tateishi, J. (2020). Redress. The Inside Story of the Successful Campaign for Japanese American Reparations. Berkeley (CA): Heyday.

Uchida, Y. [1982] (2015). Desert Exile. Seattle: University of Washington Press.

Witcover, J. (2007). Very Strange Bedfellows. The Short and Unhappy Marriage of Richard Nixon and Spiro Agnew. New York: Public Affairs.

Yamamoto, H. [1942] (2001). "Death Rides the Rails to Poston". Seventeen Syllables and Other Stories. Revised and Expanded Edition. New Brunswick (NJ): Rutgers University Press, 131-41. 
